\title{
Controlled Foreign Corporation
}

National Cancer Institute

\section{Source}

National Cancer Institute. Controlled Foreign Corporation. NCI Thesaurus. Code C54130.

An offshore company in which a U.S. person owns 10 percent or more of a foreign corporation or in which 50 percent or more of the total voting stock is owned by U.S. shareholders collectively or 10 percent or more of the voting control is owned by U.S. persons which is treated by the IRS as a U.S. tax reporting entity. 